\title{
REVITALISASI TEKS-TEKS KEARIFAN LOKAL KEMARITIMAN UNTUK MEMBANGUN KEHIDUPAN BERMASYARAKAT, BERBANGSA, DAN BERNEGARA
}

\author{
Darmoko \\ Universitas Indonesia \\ pak.darmoko@gmail.com
}

\begin{abstract}
Abstrak
Teks sebagai ungkapan bermakna suatu etnik dapat dieksplorasi sebagai kekayaan intelektual bagi siapa saja yang ingin meneliti dan menyajikannya dalam kerangka studi ilmiah akademik. Teks kearifan lokal di Indonsia terekspresikan, baik melalui tradisi tulis maupun lisan, dalam bentuk bahasa, sastra, adat istiadat, dan kesenian. Ekspresi teks-teks lisan dan tulis tersebut dapat menggambarkan tingkat pengetahuan suatu masyarakat, baik berkaitan dengan aspek pertanian maupun kemaritiman.Teks kemaritiman yang bersumber dari kearifan lokal memberikan andil yang cukup besar sebagai modal untuk membangun umat manusia dalam kehidupan bermasyarakat, berbangsa, dan bernegara. Keagungan suatu kerajaan (negara) yang berorientasi pada laut, keperwiraan dan kedigjayaan suatu tokoh penjelajah laut, peristiwa yang menggambarkan kecanggihan strategi dalam bertempur, dan ungkapan rasa bangga terhadap keberadaan laut sebagai sumber nafkah dan kehidupan merupakan nilai-nilai budaya yang dapat memberikan spirit dan motivasi bagi masyarakat untuk mempertebal rasa memiliki, membela, dan mempertahankan keutuhan masyarakat, bangsa, dan negara Indonesia. Kesadaran dan pemahaman tentang budaya lokal kemaritiman sebagai milik bangsa dapat memupuk sikap nasionalisme, patriotisme, dan cinta tanah air. Studi ilmiah akademik memberikan ruang kepada peneliti untuk mengeksplorasi korpus data teks-teks kearifan lokal kemaritiman dari berbagai konteks (perspektif), kerangka teori, dan metodologi. Perspektif sejarah, politik, ekonomi, sosiologi, sastra, linguistik, antropologi, filologi, studi kawasan, dan lain-lain memberikan konteks bagi sebuah penelitian untuk disuguhkan bagi masyarakat luas. Permasalahannya bagaimana implementasi dan produk penelitian yang bersumber dari teks-teks kearifan lokal kemaritiman dapat memberikan dampak konstruktif bagi kehidupan umat manusia dalam bermasyarakat, berbangsa, dan bernegara. Untuk menangani permasalahan ini diperlukan metodologi yang komprehensif di samping ketersediaan para pakar di bidang ilmu pengetahuan masing-masing, tata kelola (manajemen) birokrasi, serta kemauan politik pemerintah pusat dan daerah untuk menginternalisasi nilai-nilai kearifan lokal kemaritiman yang bersifat universal kepada masyarakat sebagai penjaga kesatuan dan persatuan bangsa.
\end{abstract}

Kata kunci: Revitalisasi, Kearifan Lokal, Kemaritiman

\section{PENDAHULUAN}

Sejak era reformasi bergulir di tengah percaturan politik Indonesia, sejak itu pula perubahan kehidupan mendasar berkembang di hampir seluruh kehidupan berbangsa dan bernegara, seperti merebaknya beragam krisis yang melanda Negara Kesatuan Republik Indonesia. Salah satu di antaranya berkaitan dengan orientasi pembangunan. Pada masa orde baru, orientasi pembangunan masih terkonsentrasi pada wilayah daratan. Sektor kelautan dapat dikatakan hampir tak tersentuh meskipun kenyataannya sumber daya kelautan dan perikanan yang dimiliki oleh Indonesia sangat beragam, baik jenis maupun potensinya. Potensi sumber daya tersebut terdiri atas sumber daya yang dapat diperbarui, seperti sumber daya perikanan, baik perikanan tangkap maupun budi daya laut dan pantai, energi non- konvensional dan energi serta sumber daya yang tidak dapat diperbarui, seperti sumber daya minyak dan gas bumi dan berbagai jenis mineral. Selain dua jenis sumber daya tersebut, juga terdapat berbagai macam jasa lingkungan lautan yang dapat dikembangkan untuk pembangunan kelautan dan perikanan, seperti pariwisata bahari, industri maritim, jasa angkutan, dan sebagainya. Tentunya inilah yang mendasari Presiden Abdurrahman Wahid menerbitkan Keputusan Presiden No.355/M Tahun 1999 tanggal 26 Oktober 1999 dalam Kabinet periode 1999-2004 mengangkat Ir. Sarwono Kusumaatmaja sebagai Menteri Eksplorasi Laut. (https://kkp.go.id/page/6-sejarah). Negara Republik Indonesia sebagai negara kepulauan terbesar di dunia menduduki urutan kedua dalam daftar sepuluh negara yang memiliki garis pantai terpanjang di dunia, yaitu sepanjang $54,716 \mathrm{~km}$. Urutan pertama ditempati oleh Kanada 
dengan garis pantai sepanjang $202.800 \mathrm{~km}$. Urutan ketiga adalah Greenland, yaitu sebuah divisi otonomi dari kerajaan Denmark dengan garis pantai sepanjang $44.087 \mathrm{~km}$. Dari urutan keempat sampai dengan kesepuluh berturut-turut adalah Rusia, Filipina, Jepang, Australia, Norwegia, Amerika Serikat, dan Selandia Baru (https://ilmupengetahuanumum.co/10-negaradengan-garis-pantai-terpanjang-di-dunia/).

Era pemerintahan Presiden Joko Widodo menetapkan visi pembangunan adalah "Terwujudnya Indonesia yang berdaulat, mandiri, dan berkepribadian berlandaskan gotong royong". Visi ini memberikan harapan dan mengembalikan semangat untuk memanggil kembali kejayaan maritim dengan memanfaatkan sumber daya kelautan. Kemudian visi tersebut diturunkan menjadi tujuh misi pembangunan. Tiga dari tujuh misi tersebut berhubungan dengan kemaritiman dan posisi Indonesia sebagai negara kepulauan. Adapun ketiga misi tesebut adalah (1) mewujudkan keamanan nasional yang mampu menjaga kedaulatan wilayah, menopang kemandirian ekonomi dengan mengamankan sumber daya maritim, dan mencerminkan kepribadian Indonesia sebagai negara kepulauan; (2) mewujudkan politik luar negeri bebas-aktif dan memperkuat jati diri sebagai bangsa maritim; dan (3) mewujudkan Indonesia menjadi negara maritim yang mandiri, maju, kuat, dan berbasiskan kepentingan nasional.

Pembentukan Kementerian Koordinator Kemaritiman mengedepankan konsep "Poros Maritim Dunia" dan "Tol Laut". Selain itu, Presiden Joko Widodo juga sudah menandatangani Perpres No.16/2017 tentang Kebijakan Kelautan Indonesia (Dickry Rizanny N; http://maritimnews.com/2017/05/perpres-162017dan-pembangunan-maritim-indonesia/). Indonesia juga memiliki wilayah perairan yang kaya dengan potensi cadangan energi, potensi perikanan, dan potensi pariwisata bahari. Di samping itu, juga memiliki jalur pelayaran strategis yang dapat dimanfaatkan sebagai basis pengembangan kekuatan geopolitik, ekonomi, dan budaya bahari (Kementerian PPN Bappenas, 2015, http://Nusantarainitiative.com/wpcontent/uploads/2016/02/150915-Buku-Tol-Lautbappenas.pdf)

Berdasarkan keterangan tentang orientasi pembangunan sektor kelautan dan sumber daya di dalamnya sejak era reformasi, perlu terus dikembangan.

\section{DATA DAN METODOLOGI}

Data yang digunakan sebagai titik tolak kertas kerja ini adalah teks-teks bahasa dan sastra, tradisi (adat istiadat), dan kesenian. Data yang ada dianalisis menggunakan metode deskriptif kualitatif yang bertujuan untuk mengungkap fakta, fenomena (gejala), variabel, dan keadaan yang terjadi saat penelitian berjalan dan menyuguhkannya dengan apa adanya. Penelitian kualitatif menafsirkan dan menuturkan data yang ada dengan situasi masyarakat yang sedang terjadi, seperti sikap dan pandangan, pertentangan dua keadaan atau lebih, hubungan antarvariabel, perbedaan antarfakta dari data yang ada, pengaruh terhadap situasi dan kondisi, dan lain-lain. Permasalahan yang dikaji pada penelitian kualitatif mengacu pada studi komparatif dan studi relasi sebuah unsur dengan unsur lainnya. Kegiatan penelitian ini meliputi pengumpulan data, analisis data, interprestasi data, dan penyimpulan yang mengacu pada analisis data yang telah dilakukan.

Metode deskriptif kualitatif bermanfaat untuk mengeksplorasi dan memahami makna yang dianggap berasal dari permasalahan sosial dan humaniora. Penelitian kualitatif melibatkan upaya penting, seperti mengajukan pertanyaan dan prosedur, pengumpulan data khusus dari partisipan, menganalisis data secara induktif, yaitu mulai dari tema khusus ke tema umum, kemudian menafsirkan makna data. Laporan akhir penelitian ini memiliki struktur (kerangka) yang fleksibel dan berfokus terhadap makna individual dan menerjemahkan kompleksitas suatu persoalan (Creswell, 2010: 4--5).

Teks-teks kearifan lokal kemaritiman meliputi bahasa dan sastra, tradisi (adat istiadat), dan kesenian digunakan sebagai objek kajian status dan kedudukan dalam konteks kehidupan bermasyarakat, berbangsa, dan bernegara. Objek tersebut dikaji berdasarkan implementasi fakta, fenomena (gejala), variabel, dan keadaan di samping menafsirkan dan menuturkan data yang ada dengan situasi masyarakat yang sedang terjadi. Teks-teks kearifan lokal kemaritiman dikaji dalam berbagai perspektif dan hasilnya merupakan informasi yang dapat dijadikan sebagai wahana membangun kehidupan bermasyarakat, berbangsa, dan bernegara. 


\section{PEMBAHASAN}

Di dalam kehidupan berbangsa dan bernegara ditemukan beberapa semboyan yang dipetik dari bahasa Sanskerta untuk institusi tertentu, seperti untuk TNI Angkatan Darat RI, Kartika Eka Paksi (prajurit gagah berani yang menjunjung keluhuran nusa dan bangsa serta prajurit sejati); untuk TNI Angkatan Udara RI, Swa Bhuwana Paksa (pelindung/pembela tanah airku); untuk Kepolisian RI, Rastra Sewakottama (melayani masyarakat); dan untuk TNI Angkatan Laut RI, Jalesveva Jayamahe (di laut kita jaya).

Ungkapan Jales Viva Jayamahe (di laut kita jaya) merupakan slogan yang seharusnya diwujudkan dalam kenyataan. Sejauh mana kemampuan armada laut bangsa Indonesia dalam mengawal kedaulatan lautnya. Berapa banyak penyelundupan di laut dan pencurian ikan oleh nelayan asing tidak dapat diatasi secara tuntas. Dilihat dari besarnya jumlah pulau NKRI, ternyata masih ribuan yang belum bernama dan teridentifikasi secara akurat potensinya. Bagaimana harus disikapi dengan sebuah berita tentang "nasib warga pulau terluar", ketika Camat Pulau Laut, Kabupaten Natuna, Baharuddin, mengungkapkan "terus terang, saya atas nama masyarakat Kecamatan Pulau Laut merasa sangat bahagia karena selama hidup kami, baru kali ini kami benar-benar merasakan menjadi bagian dari Negara Kesatuan Republik Indonesia. Peristiwa ini merupakan sejarah bagi masyarakat Pulau Laut". Sampai saat ini masih ribuan jumlah pulau yang belum bernama dan teridentifikasi dengan baik. Hal itu berarti bahwa masih banyak sejarah pulau yang belum dikaji. Dengan demikian, masih terbuka luas bagi kajian sejarah maritim mengenai 'pulau sejarah' yang juga terabaikan (the history of neglected islands). Suatu kajian Alex J. Ulaen patut diberikan tempat dalam konteks ini. Berlatar belakang antropologi yang kini banyak berkecimpung di bidang sejarah, ia mengungkap pulau-pulau di Kepulauan Sangihie-Talaud yang hampir terlupakan (dilihat dari sudut pandang tempatan) dalam kurun waktu masuknya pedagang dari Iberia di sana (Zuhdi, 2006).

Pada 20 Oktober 2014 Presiden Joko Widodo menyampaikan pidato sebagai berikut.

"Samudera, laut, selat, dan teluk adalah masa depan peradaban kita. Kita telah terlalu lama memunggungi laut, memunggungi samudera, selat, dan teluk sehingga jalesveva jayamahe, di laut kita jaya, sebagai semboyan nenek moyang kita di masa lalu kembali membahana”.

Pernyataan tersebut jelas adanya kemauan politik seorang Jokowi sebagai pemimpin bangsa dan negara Indonesia menginginkan adanya pemberdayaan fungsi dan eksistensi samudra, laut, teluk sebagai tumpuan harapan bagi peradaban masa depan dan menjadikan laut sebagai wahana menuju kejayaan bangsa dan negara Indonesia. Tentu saja semboyan masa lalu itu tidak hanya sebagai slogan semata. Namun, perlu implementasi dan kerja nyata dari seluruh komponen bangsa agar Indonesia benar-benar menjadi negara yang mandiri, maju, dan kuat seperti kerajaan Sriwijaya yang mengalami zaman keemasan pada masa lalu.

Sriwijaya menjadi kerajaan maritim yang mandiri, kuat, dan sejahtera karena manajemen pemerintahan yang baik, pertahanan dan keamanan yang kuat, dan melibatkan orang selat atau orang laut. Sebaliknya, Sriwijaya menjadi terpuruk tatkala pemimpinnya menempatkan sebagaian besar orang-orang daratan untuk mengisi formasi pasukannya, sementara orang laut telah menyingkir, ahli navigasi dan penyelam dari orang laut mulai berkurang. Akhirnya, Sriwijaya menjadi terbenam sebagai kerajaan maritim. Sudah saatnya Indonesia perlu menempatkan SDM di bidang kemaritiman pada bidang-bidang yang tepat seperti masa-masa kejayaan kerajaan Sriwijaya. TNI dan polisi perairan dan nakhoda-nakhoda andal yang didukung oleh awak-awak kapal profesional ditempatkan pada porsinya masing-masing.

Teks kearifan lokal kemaritiman perspektif sejarah dapat dilihat pada Sejarah Buton yang Terabaikan: Labu Rope Labu Wana merupakan sebuah ulasan yang patut didiskusikan lebih lanjut. Karya tersebut merupakan penghubung periode dinamis abad keenam belas/tujuh belas Buton, suatu periode, yang menurut penulis (Susanto Zuhdi), telah diabaikan karena hegemoni Gowa dan Ternate. Sebagai seorang sejarawan yang telah memiliki informasi solid, penulis memahami Buton sebagai pulau mencoba untuk menanggapi pengaruh internal dan eksternal dengan mengambil perspektifnya sendiri dan memanfaatkannya dari semua sarana yang tersedia untuk bertahan hidup, yaitu melalui hubungan budaya dan struktural. Buku ini terdiri atas tujuh bab, yaitu (1) pengantar, (2) wilayah Buton, (3) Labu Wana, (4) Labu Rope, (5) Kumpeni Walanda, (6) orang Kumpeni dari sudut pandang orang Buton, dan (7) simpulan. 
Kelalaian tampaknya menjadi kata kunci dalam sejarah Nusantara yang sampai batas tertentu, tidak hanya dipengaruhi oleh "daratan", tetapi juga oleh laut dan pulau-pulaunya, yang pada saat kedatangan armada kolonialisme pertama memainkan peran penting. Buku ini memberikan suatu uraian yang penting tentang bagaimana kolonialisme berkontribusi pada pengetahuan kita tentang hubungan yang rumit antara "asli" sultan dan kolonial. Hal ini membuat sketsa Buton harus menghadapi tidak hanya kekuatan Gowa dan Ternate, tetapi juga kekuasaan para penguasa Belanda laut. Bagi saya, salah satu poin paling menarik yang diungkapkan penulis adalah "budaya" dan "struktur sosial" memberikan makna, juga sumber daya sebagai kendala pada saat bersamaan. Para sultan menggunakan tradisi dan ekspresi budaya lainnya untuk melegitimasi diri mereka dan memosisikan diri di antara mereka dan dalam hubungannya dengan pulau tetangga. Namun, posisi ini tidak stabil dalam hal hubungan sosial dengan sultan lain dan kemudian dengan para kolonial. Kontestasi, preseden, dan kebutuhan untuk mengatur akses ke sumber ekonomi merupakan hal yang sangat penting. Hal yang terakhir menjadi penting untuk Belanda, tetapi penduduk setempat juga membutuhkan legitimasi budaya dalam menghubungkan fenomenafenomena ini. Penulis mencoba mengidentifikasi hal-hal berikut yang merupakan masalah inti. Pertama, hubungan sosial antara pulau-pulau dan tetangga mereka, yaitu otoritas di satu sisi dan Belanda di sisi lain yang menciptakan hubungan ambigu antara pengikut dan tuan (halaman 10), yang pada gilirannya dipengaruhi. Kedua, hubungan tidak stabil di antara mereka. Kolonial memersepsikan situasi ini dalam hal "kemitraan". Jadi, bagi mereka hal itu mungkin untuk memaksa otoritas lokal menandatangani perjanjian. Ancaman multilevel eksternal memaksa mereka mengadopsi strategi tertentu, tetapi juga merugikan karena kegagalan mereka menjaga kesetiaan. Bahkan, memimpin mereka mengubah posisi dari pemenang menjadi pecundang pada era modern. Buku ini memberikan kontribusi yang signifikan dalam hal "pulau sejarah", dan "pulau dalam sejarah", atau dalam istilah semiotik di "tanda sejarah" dan "masuk sejarah" (Christomy, 2011).

Dari objek bahasa dan sastra dapat diketengahkan sebuah judul lagu Nenek Moyangku Orang Pelaut ciptaan Ibu Soed yang dapat memberikan inspirasi bagi masyarakat yang mendengarkannya untuk selalu mengenang orangorang yang sangat profesional dalam bidang kemaritiman.

Nenek moyangku orang pelaut

Gemar mengarung luas samudera

Menerjang ombak tiada takut

Menempuh badai sudah biasa

Angin bertiup layar terkembang

Ombak berdebur di tepi pantai

Pemuda berani bangkit sekarang

Ke laut kita beramai-ramai

Syair lagu tersebut memuat konteks sejarah/genealogi yang memberikan ilustrasi tentang nenek moyang sebagai pelaut. Generasi muda juga diperkenalkan pada lingkungan hidup kemaritiman, yaitu dengan diketengahkan samudra yang berombak dan badai meskipun ombak dan badai tersebut menerjang dianggap sebagai tantangan hidup karena hidup sesungguhnya penuh tantangan dan perjuangan. Dengan demikian, generasi muda tidak perlu takut dan harus kompak menaklukkan laut.

Dari perspektif sastra, seni, dan politik teks kearifan lokal kemaritiman tergambar di dalam dunia pewayangan, dalam hal ini lakon Rama Tambak pernah digunakan oleh Soeharto melalui Joop Ave, Menparpostel, sebagai media untuk melepaskan belenggu dari krisis nasional di segala bidang pada tahun 1998 (ruwatan). Ekspresi simbolik dari lakon Rama Tambak pada pertunjukan wayang kulit purwa dimanfaatkan oleh kekuasaan (orde baru) untuk membendung prahara krisis ekonomi, sosial, politik, dan budaya pada tahun 1998. Teks kearifan lokal kemaritiman ini mempunyai relasi dengan permasalahanpermasalahan tersebut. Wayang kulit purwa berjudul Rama Tambak tersebut dipergelarkan atas prakarsa Yoop Ave, Menparpostel saat itu, yang sedikit banyak dipengaruhi oleh kekuasaan orde baru. Melalui wahana simbol Yoop Ave memainkan lakon Rama Tambak sebagai alat untuk membebaskan penderitaan rakyat dari belenggu krisis di segala bidang.

Wacana kekuasaan orde baru secara implisit tergambar di dalam lakon Rama Tambak. Upaya untuk mengadakan ruwat nasional rupanya mengalami kegagalan karena pertunjukan wayang dengan lakon tersebut tidak mampu membendung malapetaka nasional. Konstruksi wacana kekuasaan yang berkelindan di dalam wayang kulit 
purwa lakon Rama Tambak tidak mampu memengaruhi rakyat Indonesia untuk bersamasama menghentikan krisis di segala bidang. Soeharto sebagai pusat kekuasaan orde baru melalui Yoop Ave dan PEPADI gagal meruwat situasi dan kondisi secara nasional yang semakin memburuk dan akhirnya Soeharto lengser (mundur) dari jabatan kepresidenan karena desakan rakyat.

Pemanfaatan mitos lakon Rama Tambak secara tidak langsung diimplementasikan oleh Presiden Jokowi dengan sebuah konsepnya yang cukup populer, yaitu tentang rancangan dan implementasi pembangunan tol laut yang menghubungkan Medan, Batam, Jakarta, Surabaya, Makasar, hingga Sorong. Tol laut itu sendiri merupakan konsep pengangkutan logistik kelautan yang dicetuskan oleh Presiden Republik Indonesia, Joko Widodo. Program ini bertujuan untuk menghubungkan pelabuhan-pelabuhan besar yang ada di Nusantara. Dengan adanya hubungan antarpelabuhan laut ini, dapat diciptakan kelancaran distribusi barang hingga ke pelosok. Selain hal itu, juga pemerataan harga logistik setiap barang di seluruh wilayah Indonesia. Seperti dikutip dari pidato Presiden Jokowi, 5 April 2016 "Tol Laut untuk apa? Sekali lagi ini mobilitas manusia, mobilitas barang. Harga transportasi yang lebih murah, biaya logistik yang lebih murah, dan akhirnya kita harapkan harga-harga akan turun" (https://id.wikipedia.org/wiki/Tol_Laut).

Dirjen Perhubungan Laut, Agus Purnomo, menuturkan bahwa dinaikkannya subsidi (33,43\% dari tahun lalu Rp 335 miliar) bertujuan untuk mengoptimalkan fungsi tol laut dalam menjaga stabilitas harga bahan pokok di seluruh daerah. "Jadi, kita punya jaringan tol laut yang menghubungkan daerah potensial ke daerah terpencil. Tahun 2018 ini pemerintah berusaha keras supaya bagaimana harga bahan pokok beras, tepung termasuk semen dan lain-lain di daerah terpencil, harganya tidak terlalu jauh," jelasnya dalam focus group discussion di Hotel Sari Pan Pacific, Jumat (2/3/2018). Tiga pelabuhan utama dalam tol laut adalah Pelabuhan Teluk Bayur (Padang), Pelabuhan Tanjung Priok (Jakarta), dan Pelabuhan Tanjung Perak (Surabaya). (https://www.cnbcindonesia.com/news/201803021 13203-4-6000/tol-laut-jokowi-disubsidi-2018-rp447-miliar-naik-33)
Dalam hubungannya dengan konsep pembangunan tol laut yang dicanangkan oleh Jokowi, lakon Rama Tambak dapat memberikan inspirasi kepada seluruh masyarakat bahwa untuk menyeberangi lautan yang luas dengan ombak yang tinggi dan dihuni oleh makhluk mengerikan diperlukan upaya bala tentara Ramawijaya yang berupa kera untuk bergotong royong dan bahumembahu dengan semangat gugur gunung membangun tanggul laut (tol) yang berfungsi untuk menghubungan Pancawati dan Alengkadiraja. Upaya yang dilakukan oleh bala tentara kera yang dipimpin oleh Sugriwa dan Hanoman membuahkan hasil dan malapetaka laut Yuyu Rumpung dapat dipatahkan. Ramawijaya beserta bala tentara kera berhasil memasuki Alengka, terjadilah perang besar yang pada akhirnya pasukan Pancawati dapat menguasai Alengka dan melumpuhkan bala tentara Rahwana berupa raksasa. Ekspresi simbolik dalam lakon ini memberikan spirit dan motivasi kepada seluruh masyarakat bahwa laut Indonesia yang luas dengan beribu-ribu pulau yang ada dapat dihubungkan dengan pembangunan tol laut seperti halnya konsep yang dicanangkan oleh Jokowi.
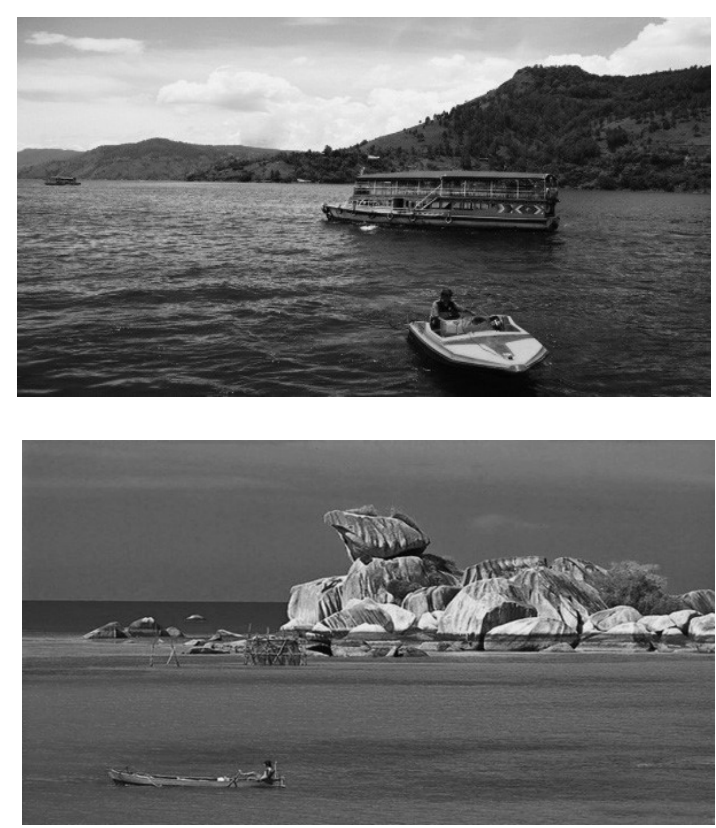

Kebijakan penyusunan kawasan wisata pada Kementerian Pariwisata RI dalam rangka pengembangan destinasi wisata dilakukan beberapa bulan lalu bersama FIBUI, menekankan pada tiga kawasan yang penting yang kontak dengan perairan, yaitu Danau Toba (Sumatra Utara), Tanjung Kelayang (Bangka Belitung), dan 
Wakatobi (Sulawesi Tenggara). Gambaran wilayah perencanaan tiga tempat wisata perairan tersebut menunjukkan bahwa kondisi wilayah sangat penting, yaitu meliputi kondisi geografis; kondisi fisik kawasan: topografi, penggunaan lahan, hidrologi; kondisi sarana dan prasarana; demografi; sosial keagamaan; tradisi dan budaya masyarakat sangat penting. Atraksi di lokasi wisata yang kontak dengan perairan merupakan daya tarik yang dapat mengundang wisatawan berupa bendabenda budaya, tradisi, ritual dan upacara, juga kesenian. Perencanaan pengembangan kawasan pariwisata kelautan, khususnya Tanjung Kelayang dan Wakatobi disertai pengembangan atraksi dan daya tarik wisata. Dalam hal ini mengembangkan objek-objek wisata yang ada; mengembangkan wisata minat khsusus berbasis event/tradisi, ritual dan upacara; mengembangkan daya tarik wisata pendukung berupa seni pertunjukan; mengembangkan daya tarik dengan menggali potensi kerajinan; mengembangkan atraksi alam, misalnya sungai, gua, laut; dan mengembangkan wisata pendidikan berbasis keagamaan.

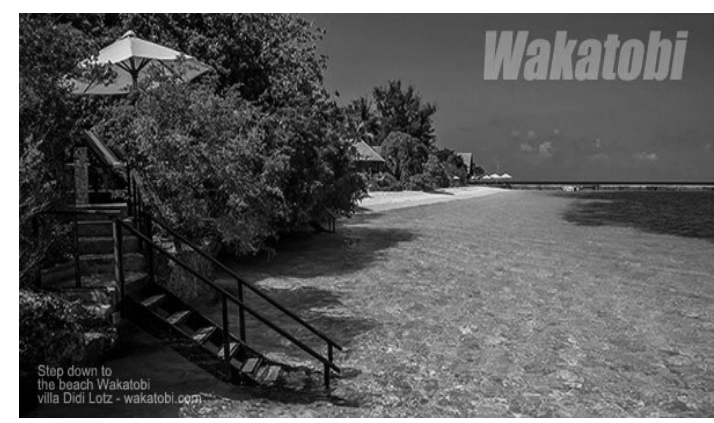

Dari hasil diskusi Tim FIB UI dan Kementerian Pariwisata disampaikan hal-hal terkait dengan pengembangan kawasan wisata daerah yang berada di pesisir, pantai, perairan laut dengan menyusun teks naratif sejarah masyarakat dan kebudayaan Desa Sijuk Belitung; menyusun narasi sejarah rumah tradisional dan benda-benda budaya masyarakat Desa Sijuk; menyusun buku teks naratif sejarah masyarakat dan kebudayaan Toba (di dua desa sebagai sampel) dan Sulawesi Tenggara; menyusun narasi sejarah rumah tradisional dan benda-benda budaya masyarakat Toba (di dua desa sebagai sampel) dan Sulawesi Tenggara; mengelola aksara dan bahasa terkait dengan idiom-idiom (ungkapan-ungkapan) budaya Batak dan Sulawesi Tenggara dalam tiga bahasa yang dipampang di tempat-tempat tertentu.
Keikutsertaan FIB UI dalam sebuah riset bersama Kementerian Pariwisata tahun ini minimal memberikan kontribusi yang signifikan terkait dengan pemikiran tentang pemberdayaan sumber daya budaya dan atraksi budaya pada destinasi wisata pesisir yang kontak dengan perairan, baik di lokasi danau maupun laut. Sumber daya budaya dan atraksi budaya yang dieksplorasi dari teks-teks kearifan lokal kemaritiman, baik terkait dengan bahasa dan sastra, adat istiadat, serta kesenian di lokasi "pantai" memberikan penguatan terhadap citra Indonesia sebagai negara yang kaya akan pulau dan perairan.

\section{SIMPULAN}

"Kajian Revitalisasi Teks-Teks Kearifan Lokal Kemaritiman untuk Membangun Kehidupan Bermasyarakat, Berbangsa, dan Bernegara" menghasilkan beberapa simpulan sebagai berikut.

Dalam konteks riset, teks-teks kearifan lokal kemaritiman memberikan peluang untuk dikaji terus-menerus oleh para pakar dari berbagai disiplin yang hasilnya dapat dipresentasikan kepada masyarakat demi kemajuan ilmu pengetahuan yang sekaligus bermanfaat sebagai sarana mencerdaskan kehidupan bangsa. Untuk membangun kehidupan masyarakat yang lebih sejahtera diperlukan sejumlah pakar yang andal dari berbagai bidang ilmu pengetahuan, baik sejarah, politik, sosial, ekonomi, maupun budaya untuk menangani permasalahan teks-teks kearifan lokal kemaritiman yang muaranya adalah tercapainya wawasan kebangsaan yang kokoh dan maju. Kearifan lokal kemaritiman memberikan perspektif ekspresi simbolik terhadap realitas sosial yang diproyeksikan dalam kehidupan bermasyarakat, berbangsa, dan bernegara. Lakon Rama Tambak dalam seni pertunjukan wayang sebagai eskpresi simbolik memberikan spirit dan daya hidup terhadap penyelenggara negara untuk mengimplementasikan pembangunan tol laut dan menyatukan tanah air Indonesia sebagai negara kepulauan.

Dalam konteks manajemen (tata kelola) birokrasi, pemberdayaan teks-teks kearifan lokal kemaritiman memerlukan adanya sinergitas kerja sama yang erat dan kokoh di bawah koordinasi Menteri Koordinator Bidang Kemaritiman, yang mengoordinasikan Kementerian Kelautan dan Perikanan, Kementerian Perhubungan, Kementerian Energi dan Sumber Daya Mineral, 
serta Kementerian Pariwisata yang didukung lembaga swadaya masyarakat dan pemerintah daerah untuk meningkatkan taraf hidup yang lebih sejahtera dengan mewujudkan wisata bahari yang khas disertai eksplorasi sumber daya budaya dan atraksi budaya lokal. Teks-teks kearifan lokal kemaritiman memberikan identitas (jati diri) kepada masyarakat pendukungnya untuk membangun citra Indonesia sebagai negara maritim yang kaya akan sumber daya mineral dan sumber daya budaya.

Dalam konteks politik, pengembangan wawasan Nusantara melalui kesadaran akan pentingnya pemahaman tentang keragaman teksteks kearifan lokal kemaritiman yang tersebar di seluruh pelosok tanah air dapat memberikan penguatan terhadap empat saka guru kebangsaan, yaitu Pancasila, UUD '45, Bhinneka Tunggal Ika, dan NKRI. Teks-teks kearifan lokal yang memuat sejarah masa lalu memberikan perspektif kepada kehidupan masa datang agar lebih taktis dan strategis serta efektif dan efisien dalam mengambil suatu keputusan atas kebijakan yang menyangkut hajat hidup orang banyak. Labu Wana Labu Rope: Sejarah Butun Abad XVII memberikan perspektif masa depan yang lebih cerah dan terbuka tentang perlunya wawasan kemaritiman untuk membangun wawasan Nusantara demi terciptanya persatuan dan kesatuan bangsa.

\section{DAFTAR PUSTAKA}

Christomy, Tommy. 2011. Sejarah Buton yang Terabaikan: Labu Rope Labu Wana. Jakarta: Rajawali Pers, Yayasan Kebudayaan Masyarakat Buton, 2010, xli +350 pages (including illustrations and maps). ISBN 9789797692292. Tinjauan Buku dalam Jurnal Wacana Vol. 13, No. 2. Artikel dalam file://CC:/Users/Acer/AppData/Local/Temp/S usanto_Zuhdi_Sejarah_Buton_yang_terabaik an_Labu_r-1.pdf.

Creswell, John W. 2010. Research Design: Pendekatan Kualitatif, Kuantitatif, dan Mixed. (Achmad Fawaid, penerjemah). Yogyakarta: Pustaka Pelajar.

Darmoko. 2013. Wacana Kekuasaan dalam Wayang Kulit Purwa: Tinjauan pada Lakon Rama Tambak. Artikel pada Seminar Ramayana dengan tema "Ramayana Referensi Tekstual dan Latar Belakang
Budaya dalam Konteks Indonesia" oleh Jurusan Sastra Nusantara Program Studi Sastra Jawa, FIBUGM 5 Juni 2013 di Joglo Plawangan Boutique Jl. Raya Pakem Turi, Karang Gawang, Girikerto, Turi, Sleman, Yogyakarta.

\section{Dickry Rizanny N. 2017. Perpres 16/2017 dan} Pembangunan Maritim Indonesia http://maritimnews.com/2017/05/perpres162017-dan-pembangunan-maritimindonesia/)

Kementerian PPN Bappenas. 2015. Laporan Implementasi Tol Laut 2015 Direktorat Transportasi Kementerian PPN Bappenas: Implementasi Konsep Tol Laut 2015-2019. Artikel http://Nusantarainitiative.com/wppada content/uploads/2016/02/150915-Buku-TolLaut-bappenas.pdf. Sejarah Kementerian Kelautan dan Perikanan dalam https://kkp.go.id/page/6-sejarah.

Yuliati. 2014. "Kejayaan Indonesia sebagai Negara Maritim". Jurnal Pendidikan Pancasila dan Kewarganegaraan Th. 27, Nomor 2, Agustus 2014. Artikel pada file:///C:/Users/Acer/AppData/Local/Temp/5 523-4795-1-SM.pdf.

Zuhdi, Susanto. 1999. "Labu Wana Labu Rope: Sejarah Buton Abad XVII".Disertasi Universitas Indonesia.

Perkembangan $2006 . \quad$ Laut, Sungai, dan Asia Tenggara, Indonesia dan Metodologi Strukturis". Artikel Konferensi Nasional Sejarah VIII di Jakarta, 14-16 November 2006. Artikel padahttp://www.geocities.ws/konferensinasi onalsejarah/susanto_zuhdi_konferensifinal.pdf.

. "Budaya Maritim, Kearifan Lokal, dan Diaspora Buton". Artikel dalam https://icssis.files.wordpress.com/2012/05/06 09082010_18.pdf. 


\section{Biografi Pendek:}

Darmoko adalah seorang dosen pada Program Studi Jawa, Departemen Kewilayahan (Area Studies), Fakultas Ilmu Pengetahuan Budaya
Universitas Indonesia, Kampus Depok. Ia meraih gelar doktor pada 15 Mei 2017 dengan judul disertasi "Wayang Kulit Purwa Lakon Semar Mbabar Jatidiri: Sanggit dan Wacana Kekuasaan Soeharto". 